\title{
Pengaruh Dosis Pupuk Guano Terhadap Pertumbuhan dan Hasil Beberapa Varietas Tanaman Tomat (Lycopersicum esculentum L.)
}

\author{
(The Effects of Guano Fertilizer Dosage on the Growth and the Result of \\ Some Tomato (Lycopersicum esculentum L.) Plant Varieties)
}

\author{
Rifky Indra ${ }^{1}$, Marai Rahmawati ${ }^{1}$, Rita Hayati ${ }^{1 *}$ \\ ${ }^{1}$ Jurusan Agroteknologi, Fakultas Pertanian, Universitas Syiah Kuala
}

\begin{abstract}
Abstrak. Penelitian ini bertujuan untuk mengetahui pertumbuhan dan hasil tanaman tomat pada berbagai dosis pupuk guano terhadap beberapa varietas tomat. Penelitian ini menggunakan Rancangan Acak Kelompok pola faktorial 4 x 3 dengan 3 ulangan yang terdiri dari 2 faktor perlakuan. Faktor pertama dosis pupuk guano terdiri dari 4 taraf yaitu kontrol, 7,5 ton/ha, 15 ton/ha dan 22,5 ton/ha. Faktor kedua varietas tomat yang terdiri dari 3 varietas yaitu Betavila F1, Permata F1 dan Servo F1. Parameter pertumbuhan yang diamati adalah tinggi tanaman, diameter pangkal batang dan jumlah daun 15, 30 dan 45 HST. Parameter hasil yang diamati adalah jumlah buah per tanaman, berat buah per tanaman, diameter buah, berat per buah dan produksi buah per hektar. Hasil penelitian menunjukkan bahwa dosis pupuk guano berpengaruh nyata terhadap jumlah daun umur 30 HST, namun tidak berpengaruh nyata pada peubah lainnya. Pertumbuhan dan hasil tanaman tomat yang cenderung lebih baik dijumpai pada dosis pupuk guano 22,5 ton/ha. Hasil penelitian menunjukkan bahwa varietas berpengaruh sangat nyata terhadap jumlah daun umur 45 HST, berat per buah, diameter buah, berat buah per tanaman dan produksi buah per hektar. Berpengaruh nyata terhadap tinggi tanaman umur 45 HST dan jumlah buah per tanaman. Pertumbuhan dan hasil tanaman tomat terbaik dijumpai pada varietas Servo. Tidak terdapat interaksi antara dosis pupuk guano dengan varietas terhadap semua peubah yang diamati.
\end{abstract}

Kata kunci: Dosis Pupuk guano, Tomat, Varietas

\begin{abstract}
Abstrak : The study aims to determine the growth and the result of tomato plants with some variances fertilizer dosage on several tomato varieties. This study used a Randomized Block Design 4 x 3 factorial pattern with 3 recurring that is consist of 2 treatment factors. The first factor of guano fertilizer dosage consist of 4 levels which are control, 7,5 ton/ha, 15 ton/ha and 22,5 ton/ha. The second factor of tomato varieties consist which are Betavila F1, Permata F1 and Servo F1. The growth of variable that observed were the plant height, diameter of stem base and the number of leaves 15, 30 and 45 HST. The result of variable that observed were the number of fruits per plant, the weight of fruits per plant, the fruits diameter, the weight per fruits and production of fruits per hectare. The result showed that thr dosage of guano fertilizer had a significant effect on number of leaves aged 30 HST, but it had not significantly effect on other variable. The growth and result of tomato plants were have tend better found on guano fertilizer dosage 22,5 ton/ha. The result showed that the varieties had a very significant effect on number of leaves aged 45 HST, weight per fruits, fruits diameter, weight of fruits per plant and production of fruits per hectare. It also had a significant effect on plant height aged 45 HST and number of fruits per plant. The growth and result of the best tomato plant have found on Servo F1 variety. There is no interaction between the guano fertilizer dosage and the varieties of all observed variables.
\end{abstract}

Keyword : Guano fertilizer dosage, Tomato, Varieties 


\section{PENDAHULUAN}

Tomat (Lycopersicum esculentum L.), merupakan salah satu jenis sayuran buah yang memiliki kandungan gizi yang tinggi seperti vitamin, mineral, kabohidrat, protein, lemak dan kalori (Rismundar, 2001). Tomat berasal dari negara Peru dan Ekuador dan di tanam di Indonesia setelah kedatangan bangsa belanda (Cahyono, 2008).

Badan Pusat Statistik (BPS) menyatakan bahwa produksi tomat pada tahun 2011-2013 mengalami peningkatan yaitu, 17.358 menjadi 34.846 ton/tahun sedangkan pada tahun 2014-2015 mengalami penurunan yaitu, 30.035 menjadi 21.093 ton/tahun.

Tanaman membutuhkan unsur hara yang cukup untuk pertumbuhan dan hasil yang optimal dengan dilakukannya pemupukan(Susanti et al., 2008). Pemupukan yang dilakukan dengan menggunakan pupuk organik seperti pupuk guano dapat meningkatkan produksi tanaman.

Pupuk guano adalah pupuk organik yang berasal dari kotoran kelelawar yang dapat ditemukan di dalam gua. Kandungan yang terdapat pada guano yaitu, $2 \%$ K, 5\% P dan 16\% N. (Sediarso, 1999).

Guano yaitu sisa metabolisme dari kelelawar yang kaya akan nutrisi mikro dan makro. Kelelawar yang mengkonsumsi serangga menghasilkan unsur hara fosfor yang lebih baik (Widjanarko, 2003). Adapun unsur hara yang di hasilkan oleh kelelawar yang di kemukakan oleh Lingga dan Marsono (2004), yaitu $14 \% \mathrm{~N}, 13 \% \mathrm{P}$ dan $3 \% \mathrm{~K}$ sedangkan menurut Sugianto (2010), mengandung unsur hara $0,95 \%$ N, $3 \% \mathrm{P}$ dan $1 \% \mathrm{~K}$.

Adapun manfaat dari pupuk guano yaitu, memperbaiki kesuburan tanah, menambah jumlah dan aktifitas mikroba dalam tanah dan untuk pertumbuhan tunas dan akar (Balipost, 2005). Kotoran kelelawar menghasilkan nutrisi yang baik bila dijadikan pupuk organik yang akan berpotensi untuk meningkatkan produksi tanaman dan dapat mempercepat proses penguraian didalam tanah sehingga unsur hara yang disediakan tercukupi (Prasetyo, 2006). Unsur yang di hasilkan dari kotoran kelelawar berpotensi baik untuk dijadikan pupuk organik (Malagon, 2004).

Selain pemupukan faktor lainnya yang menyebabkan rendahnya produktivitas tomat yaitu penggunaan varietas kurang sesuai. Varietas merupakan faktor yang membantu pertumbuhan dan hasil tanaman. Menggunakan varietas unggul dapat meningkatkan produksi tanaman. Kelebihan varietas unggul dengan varietas lokal adalah produksinya yang tinggi dan tahan terhadap serangan hama dan penyakit (Soegito dan Adie, 1993).

Pada dasar nya tomat akan jauh lebih baik pada pertumbuhan maupun hasil jika di tanam pada dataran menengah (Purwati dan Khairunisa, 2009). Untuk mengetahui pemberian dosis pupuk guano dan varietas yang tepat pada tanaman tomat, perlu dilaksanakan penelitian tentang pengaruh dosis pupuk guano terhadap pertumbuhan dan hasil beberapa varietas tanaman tomat. 


\section{METODE PENELITIAN}

Penelitian ini dilaksanakan di Gampong Lamgugop dan Fakultas Pertanian Universitas Syiah Kuala Banda Aceh. Varietas yang digunakan dalam penelitian ini yaitu, varietas Betavila F1, Permata F1 dan Servo F1. Pupuk guano yang digunakan yaitu, pupuk guano yang berasa dari kotoran kelelawar yang diproduksi oleh PT. Wedhatama Sukses Makmur, Bali sebanyak $8,1 \mathrm{~kg}$.

Penelitian ini menggunakan Rancangan Acak Kelompok pola faktorial yang terdiri dari dua faktor perlakuan yaitu, Faktor pertama pupuk guano (G) terdiri dari empat taraf, $\mathrm{G}_{0}=$ kontrol, $\mathrm{G}_{1}=37,5 \mathrm{~g} / \mathrm{polibag}, \mathrm{G}_{2}=75$ $\mathrm{g} /$ polibag dan $\mathrm{G}_{3}=112,5 \mathrm{~g} /$ polibag. Faktor kedua varietas tomat $(\mathrm{V})$ terdiri dari tiga jenis, $\mathrm{V}_{1}=$ varietas Betavila $\mathrm{F} 1, \mathrm{~V}_{2}=$ varietas Permata $\mathrm{F} 1$ dan $\mathrm{V}_{3}=$ varietas Servo F1.

Pelaksanaan Penelitian yang dilakukan diawali dengan media tanam yang digunakan yaitu, lapisan atas. Kemudian diayak menggunakan ayakan dengan ukuran 9 mesh lalu tanah di campurkan dengan pupuk guano. Selanjutnya dimasukkan kedalam poibag dengan ukuran $10 \mathrm{~kg}$. Pemeliharan yang dilakukan yaitu, penyiraman, penyulaman, pengajiran, penyiangan gulma, penggemburan, pemangkasan dan pengendalian hama dan penyakit. Pemanenan dilakukan pada umur 75 HST. Parameter yang diamati yaitu, tinggi tanaman, diameter pangkal batang, jumlah daun, jumlah buah per tanaman, berat buah per tanaman, diameter buah, berta per buah dan produksi buah per hektar. 


\section{HASIL DAN PEMBAHASAN}

\section{Pengaruh Dosis Pupuk Guano Terhadap Pertumbuhan dan Hasil Tanaman tomat}

Tabel 1. Rata-rata tinggi tanaman, diameter pangkal batang, jumlah daun, jumlah buah per tanaman, berat per buah, diameter buah, berat buah per tanaman dan produksi bua per hektar pada perlakuan dosis pupuk guano

\begin{tabular}{lccccc}
\hline \multirow{2}{*}{ Peubah } & \multicolumn{4}{c}{ Pupuk Guano (ton/ha) } & BNJ \\
\cline { 2 - 4 } & $\mathrm{G}_{0}(0)$ & $\mathrm{G}_{1}(7,5)$ & $\mathrm{G}_{2}(15)$ & $\mathrm{G}_{3}(22,5)$ & 05 \\
\hline Tinggi Tanaman (cm) & & & & & \\
15 HST & 28,14 & 26,77 & 28,17 & 28,66 \\
30 HST & 72,99 & 66,15 & 72,84 & 73,57 \\
45 HST & 95,82 & 93,14 & 96,42 & 98,95 \\
Diameter Pangkal Batang (mm) & & & & \\
15 HST & 7,12 & 6,82 & 6,92 & 7,09 \\
30 HST & 14,68 & 14,53 & 14,49 & 14,72 \\
45 HST & 10,90 & 10,75 & 10,89 & 10,91 & \\
Jumlah Daun (helai) & & & & \\
15 HST & 8,00 & 7,61 & 7,78 & 8,06 & \\
30 HST & $16,61 \mathrm{~b}$ & $14,67 \mathrm{a}$ & $15,67 \mathrm{ab}$ & $15,94 \mathrm{ab}$ & 1,66 \\
45 HST & 27,33 & 27,22 & 25,83 & 28,50 & \\
Jumlah Buah Per tanaman (buah) & 12,72 & 12,39 & 11,11 & 12,72 & \\
Berat Per buah (g) & 36,03 & 34,47 & 31,54 & 34,80 & \\
Diameter Buah (mm) & 39,28 & 36,14 & 33,74 & 35,86 & \\
Berat Buah Per tanaman (g) & 474,31 & 459,04 & 423,01 & 498,85 & \\
Produksi Buah Per hektar (ton/ha) & 14,23 & 13,77 & 12,69 & 14,97 & \\
\hline
\end{tabular}

Keterangan : Angka yang diikuti oleh huruf yang sama pada kolom yang sama berbeda tidak nyata pada taraf peluang $5 \%$ (uji BNJ ${ }_{0,05}$ )

Hasil analisis ragam menuunjukkan bahwa dosis pupuk guano berpengaruh nyata terhadap jumlah daun umur 30 HST, namun tidak berpengaruh nyata terhadap jumlah daun umur 15 dan 45 HST, tinggi tanaman umur 15, 30 dan 45 HST, diameter pangkal batang umur 15, 30 dan 45 HST, jumlah buah per tanaman, berat per buah, diameter buah, berat buah per tanaman dan produksi buah per hektar. Rata-rata nilai parameter pertumbuhan dan hasil pada berbagai dosis pupuk guano setelah di uji lanjut BNJ 0,05 dapat dilihat pada Tabel 1.

Tabel 1 menunjukkan bahwa secara statistik dosis pupuk guano berpengaruh nyata pada jumlah daun $30 \mathrm{HST}$, kontrol menunjukkan hasil yang cenderung lebih baik. Hal ini menunjukkan bahwa kondisi media tanam menyediakan unsur hara yang dibuthkan untuk pertumbuhan tanaman tomat pada usia tersebut.

Tanaman dengan unsur hara yang cukup akan meningkatkan pertumbuhan dan hasil (Wibisono dan Basri, 1993). Nitrogen yang tercukupi akan menghasilkan keseimbangan rasio akar dan daun, dan mengakibatkan masa vegetatif menjadi sempurna. Ketika masa vegetatif 
sempurna maka akan mengakibatkan pertumbuhan yang baik pada masa generatif (Bandhaso et al., 2014)

Dosis pupuk guano 7,5 ton/ha, 15 ton/ha dan 22,5 ton/ha menunjukkan tidak berpengaruh nyata pada tinggi tanaman 15, 30, $45 \mathrm{HST}$, diameter pangkal batang 15, 30, 45 HST, jumlah daun 15, 45 HST, jumlah buah per tanaman, diameter buah, berat per buah, berat buah per tanaman dan produksi buah per hektar. Meskipun parameter yang diamati tidak nyata, nilai rata-rata tanaman tomat cenderung lebih baik ditemukan pada dosis pupuk guano 22,5 ton/ha. Adapun hasil penelitian ini menunjukkan bahwa dari level 7,5-22,5 ton/ha tidak mampu mencukupi unsur hara, dan ada faktor lain yang mempengaruhi pertumbuhan dan hasil tanaman yaitu fisik, kimia dan biologi tanah. Sehingga tidak memberikan pengaruh yang signifikan terhadap kendisi media tanam tanaman tomat.

Faktor pembentuk tanah menentukan kesuburan tanah karena setiap tanah memiliki tingkat kesuburan yang berbeda-beda, adapun keseimbangan antara ketiga sifat tanah seperti fisik, kimia dan biologi tanah. Sifat tanah ini saling berkesinambungan dan sangat menentukan tingkat kesuburan tanah pertanian. Fisik tanah meliputi tekstur, warna, struktur, kelembaban dan tata udara tanah. Pemberian pupuk organik kedalam tanah dapat memperbaiki kesuburan fisik tanah. Kimia tanah yaitu $\mathrm{pH}$ tanah, unsur organik dan unsur hara, secara kimia jumlah unsur hara yang terdapat pada tanah tidak tersedia dalam jumlah yang besar dan biologi tanah yaitu kegiatan mikrobia perubah unsur organik didalam tanah. Pemberian pupuk organik juga dapat meningkatkan aktivitas jasad-jasad hidup mikro didalam tanah karena bahan organik merupakan sumber makanan jasad-jasad hidup mikro tersebut, sehingga tanah menjadi subur (Ihda, 2016). 


\section{Pengaruh Varietas Terhadap Pertumbuhan dan Hasil Tanaman Tomat}

Tabel 2. Rata-rata tinggi tanaman, diameter pangkal batang, jumlah daun, jumlah buah per tanaman, berat per buah, diameter buah, berat buah per tanaman dan produksi buah per hektar pada perlakuan varietas

\begin{tabular}{lcccc}
\hline \multirow{2}{*}{ Peubah } & \multicolumn{3}{c}{ Varietas } & \\
\cline { 2 - 3 } & $\begin{array}{c}\mathrm{V}_{1} \\
\text { (Betavila) }\end{array}$ & $\mathrm{V}_{2}$ (Permata) & $\begin{array}{c}\mathrm{V}_{3} \\
(\text { Servo) }\end{array}$ & BNJ $_{0,05}$ \\
\hline Tinggi Tanaman (cm) & 27,80 & 28,82 & 27,18 & \\
15 HST & 71,73 & 69,69 & 72,74 & \\
30 HST & $97,63 \mathrm{ab}$ & $89,18 \mathrm{a}$ & $101,43 \mathrm{~b}$ & 11,24 \\
45 HST & & & & \\
Diameter Pangkal Batang (mm) & 7,16 & 6,83 & 6,97 & \\
15 HST & 14,80 & 14,68 & 14,33 & \\
30 HST & 11,09 & 10,88 & 10,61 & \\
45 HST & 7,83 & & & \\
Jumlah Daun (helai) & 16,00 & 15,67 & 15,50 & \\
15 HST & $28,75 \mathrm{~b}$ & $22,92 \mathrm{a}$ & $30,00 \mathrm{~b}$ & 4,90 \\
30 HST & $12,17 \mathrm{ab}$ & $10,04 \mathrm{a}$ & $14,50 \mathrm{~b}$ & 3,54 \\
45 HST & $37,69 \mathrm{~b}$ & $25,24 \mathrm{a}$ & $39,71 \mathrm{~b}$ & 10,16 \\
Jumlah Buah Per tanaman (buah) & $39,12 \mathrm{~b}$ & $29,39 \mathrm{a}$ & $40,25 \mathrm{~b}$ & 7,84 \\
Berat Per buah (g) & $501,26 \mathrm{~b}$ & $323,68 \mathrm{a}$ & $566,47 \mathrm{~b}$ & 153,61 \\
Diameter Buah (mm) & $15,04 \mathrm{~b}$ & $9,71 \mathrm{a}$ & $16,99 \mathrm{~b}$ & 4,58 \\
Berat Buah Per tanaman (g) & & & \\
Produksi Buah Per hektar (ton/ha) & & & & \\
\hline
\end{tabular}

Keterangan : Angka yang diikuti oleh huruf yang sama pada kolom yang sama berbeda tidak nyata pada taraf peluang $5 \%$ (uji $\mathrm{BNJ}_{0,05}$ )

Hasil analisis ragam menunjukkan varietas berpengaruh sangat nyata pada jumlah daun 45 HST, berat pe buah, diameter buah, terhadap tinggi tanaman 45 HST dan jumlah buah per tanaman, tetapi tidak berpengaruh nyata terhadap tinggi tanaman 15 dan 30 HST, diameter pangkal batang 15, 30 dan 45 HST dan jumlah daun 15 dan 30 HST. Rata-rata nilai parameter pertumbuhan dan hasil pada pengaruh varietas dapat dilihat pada Tabel 2.

Pada tabel 2 varietas berpengaruh sangat nyata pada jumlah daun 45 HST, diameter buah, berat per buah, berat buah per tanaman dan produksi buah per hektar. Berpengaruh nyata terhadap tinggi tanaman 45 HST dan jumlah buah per tanaman. Varietas Servo menunjukkan hasil lebih baik pada pertumbuhan dan hasil dibandingkan dengan varietas Permata dan varietas Betavila. Perbedaan pertumbuhan dan hasil dari berbagai varietas karena adanya perbedaan genetik dari masing-masing varietas dan lingkungan, sehingga akan memberikan pengaruh yang berbeda.

Secara deskripsi tanaman tomat varietas Betavila, Permata dan Servo menunjukkan bahwa pada parameter terdapat perbedaan dengan hasil 
penelitian yang diperoleh. Diameter buah terbesar 40,25 $\mathrm{mm}$ dijumpai pada varietas Servo $\left(\mathrm{V}_{3}\right)$, sedangkan secara deskripsi diameter buah terbesar 53,4 mm dijumpai pada varietas Betavila $\left(\mathrm{V}_{1}\right)$. Berat per buah terberat $39,71 \mathrm{~g}$ dijumpai pada varietas Servo $\left(\mathrm{V}_{3}\right)$, sedangkan secara deskripsi berat per buah terberat $84,5 \mathrm{~g}$ dijumpai pada varietas Betavila $\left(\mathrm{V}_{1}\right)$. Berat buah per tanaman terberat 566,47 g dijumpai pada varietas Servo $\left(\mathrm{V}_{3}\right)$, sedangkan secara deskripsi berat buah per tanaman terberat $2.110 \mathrm{~g}$ dijumpai pada varietas Servo $\left(\mathrm{V}_{3}\right)$. Produksi buah per hektar terberat 16,99 ton/ha dijumpai pada varietas Servo $\left(\mathrm{V}_{3}\right)$, sedangkan secara deskripsi produksi buah per hektar terberat 46,59 ton/ha dijumpai pada varietas Betavila $\left(\mathrm{V}_{1}\right)$. Tinggi tanaman tertinggi $101,43 \mathrm{~cm}$ dijumpai pada varietas Servo $\left(\mathrm{V}_{3}\right)$, sedangkan secara deskripsi tinggi tanaman tertinggi $120 \mathrm{~cm}$ dijumpai pada varietas Betavila $\left(\mathrm{V}_{1}\right)$ dan jumlah buah per tanaman terbanyak 15 buah dijumpai pada varietas Servo $\left(\mathrm{V}_{3}\right)$, sedangkan secara deskripsi jumlah buah per tanaman terbanyak 31 buah dijumpai pada varietas Servo $\left(\mathrm{V}_{3}\right)$.

Menurut pendapat Adrianus (2012), adanya pengaruh genetik dan lingkungan yang mengakibatkan perbedaan pada pertumbuhan dan hasil pada setiap individu, genetik adalah sifat yang berasal dari keturunan varietas dan lingkungan merupakan keadaan suatu tempat atau habitat yang dapat mempengaruhi pertumbuhan dan hasil.

Hasil penelitian menunjukkan bahwa varietas tidak berpengaruh nyata pada tinggi tanaman 15, $30 \mathrm{HST}$, diameter pangkal batang 15, 30, 45 HST dan jumlah daun 15, $30 \mathrm{HST}$. Varietas Betavila $\left(\mathrm{V}_{1}\right)$ menunjukkan hasil yang cenderung lebih baik pada diameter pangkal batang 15, 30, 45 HST dan jumlah daun 30 HST dibandingkan dengan varietas Permata $\left(\mathrm{V}_{2}\right)$ dan varietas Servo $\left(\mathrm{V}_{3}\right)$. Namun varietas Permata menunjukkan hasil yang cenderung lebih baik pada tinggi tanaman 15 HST dibandingkan dengan varietas Betavila $\left(\mathrm{V}_{1}\right)$ dan varietas Servo $\left(\mathrm{V}_{3}\right)$. Sedangkan varietas Servo menunjukkan hasil yang cenderung lebih baik pada tinggi tanaman 30 HST dan jumlah daun 15 HST dibandingkan dengan varietas Betavila $\left(\mathrm{V}_{1}\right)$ dan varietas Permata $\left(\mathrm{V}_{2}\right)$. Penampilan karakter setiap varietas didapat dari faktor genetik dari varietas. Perbedaan genetik menyebabkan penampilan fenotif tanaman dengan menghasilkan ciri dan sifat yang khusus berbeda antara satu sama lain akibat pengaruh lingkungan.

Secara deskripsi tanaman tomat varietas Betavila menunjukkan bahwa pada parameter terdapat persamaan dengan hasil penelitian yang diperoleh. Namun hasil yang diperoleh cenderung lebih kecil, diameter pangkal batang terbesar 11,09 mm dijumpai pada varietas Betavila $\left(\mathrm{V}_{1}\right)$, sedangkan secara deskripsi diameter pangkal batang terbesar $12 \mathrm{~mm}$ dijumpai pada varietas Betavila $\left(\mathrm{V}_{1}\right)$. Menurut pendapat Dachlan (2008), yang menyatakan bahwa perbedaan yang dapat terjadi pada setiap varietas diakibatkan oleh adanya variasi genetik yang dapat berbeda dari masing-masing varietas tersebut.

Tidak adanya interaksi yang di timbulkan antara dosis pupuk guano dan varietas terhadap pertumbuhan dan hasil tanaman tomat. 


\section{KESIMPULAN DAN SARAN}

Dosis pupuk guano pada taraf 7,5 ton/ha, 15 ton/ha dan 22,5 ton/ha tidak adanya pengaruh yang nyata pada parameter yang diamati. Dosis pupuk guano dengan taraf yang telah ditentukan tidak dapat mencukupi kebutuhan hara tumbuhan pada fase vegetatif dan generatif tanaman tomat. Dosis yang cenderung lebih baik dijumpai pada 22,5 ton/ha. Faktor varietas berpengaruh sangat nyata pada jumlah daun 45 HST, diameter buah, berat per buah, berat buah per tanaman dan produksi buah per hektar. Adanya pengaruh nyata pada tinggi tanaman 45 HST dan jumlah buah per tanaman. Varietas terbaik dijumpai pada varietas servo. Saran dari peneliti adalah perlu dilakukan analisis kadar unsur-unsur yang terdapat pada tanah dan pupuk guano agar dosis pupuk guano yang diberikan pada tanaman lebih akurat, serta memilih varietas benih tomat yang sesuai terhadap lingkungan.

\section{DAFTAR PUSTAKA}

Adrianus. 2012. Pertumbuhan dan hasil tiga varietas ubi jalar (Ipomoea batatas L.) pada tinggi petakan yang berbeda. Jurnal Agricola. 2 (1) : 49-69.

Badan Pusat Statistik. Produksi Tomat Didaerah Aceh Tahun 2015. https://www.bps.go.id/ site/. [15 Desember 2018].

Balipost. 2005. Pupuk Organik Ramah Lingkungan. Http://www.co.id/BalipostCetak/2005/ 4/24/11.Htm. [15 Desember 2018].

Bandhaso, D.T., L. Sarido dan Rudi. 2014. Uji dosis pupuk guano terhadap pertumbuhan dan hasil tanaman jagung manis (Zea mays saccharata L.). Jurnal Pertanian Terpadu. 3 (1) : 129-143.

Cahyono, B. 2008. Usaha Tani dan Penanganan Pascapanen. Kanisius, Yogyakarta.

Dachlan, A., E. Syam'un dan A.U. Singkerru. 2008. Pertumbuhan dan produksi tiga varietas padi pada berbagai paket pemupukan $\mathrm{N}$ sintetik bakteri Azotobacter. Jurnal Agrivigor. 7 (3) : 230-240.

Hardianti, A.R., Y.S. Rahayu dan M.T. Asri. 2014. Efektivitas waktu pemberian Trichoderma harzianum dalam mengatasi serangan layu Fusarium pada tanaman tomat varietas ratna. Jurnal LenteraBio. 3 (1) : 21-25.

Ihda, A.Y.S. 2016. Pengaruh sifat fisika, kimia dan biologi bagi kesuburan tanah. Skripsi. Program Studi Agroteknologi, Fakultas Pertanian Universitas Muhammadiyah Yogyakarta, Yogyakarta. 
Laude, S dan A.B.D. Hadid. 2007. Respon tanaman bawang merah terhadap pemberian pupuk organik cair. Jurnal Agrisains. 8 (3) : 140-146.

Lingga, P. dan Marsono. 2004. Petunjuk Penggunaan Pupuk. Penebar Swadaya, Jakarta.

Malagon, O.P. 2004. Part of Agriluca Export-Import. http://www.batguano.com/english/ analisis. [15 Desember 2018].

Marliah, A., M. Hayati dan I. Muliansyah. 2012. Pemanfaatan pupuk organik cair terhadap pertumbuhan dan hasil beberapa varietas tomat (Lycopersicum esculentum L.). Jurnal Agrista. 16 (3) : 122-128.

Marsono dan P. Sigit. 2001. Pupuk Akar Jenis dan Aplikasinya. Penebar Swadaya, Jakarta.

Prasetyo, S. 2006. Guano Bahan Pupuk Organik Yang Diremehkan. Sinar Harapan, Jakarta.

Purwati, E. dan Khairunisa. 2009. Budidaya Tomat Dataran Rendah. Penebar Swadaya, Jakarta.

Rahadi, V.P. 2008. Pengaruh pupuk kandang sapi dan pupuk guano terhadap produksi kedelai (Glycine $\max$ L.) organik panen muda. Skripsi. Program Studi Agronomi, Fakultas Pertanian Institut Pertanian Bogor. Bogor.

Rismundar. 2001. Tanaman Tomat. Sinar Baru Algensindo, Bandung.

Sediyarso, M. 1999. Fosfat Alam sebagai Bahan Baku dan Pupuk Fosfat. Pusat Penelitian Tanah dan Agroklimat Bogor, Bogor.

Soegito dan Adie. 1993. Bertanam Cabai. Penebar Swadaya, Jakarta.

Sugianto, E. 2010. Pupuk Organik dari Guano. http://guanophosphat.blogspot.com. [15 Desember 2018].

Susanti, H., S.A. Aziz dan M. Melati. 2008. Produksi biomassa dan bahan bioaktif kolesom (Talinum triangulare (Jacq.) Willd) dari berbagai asal bibit dan dosis pupuk kandang ayam. Jurnal Bul Agron. 36 (1) : 48-55.

Wang, Y.P., B.Z. Houlton dan C.B. Field. 2007. A model of biogeochemical cycles of carbon, nitrogen and phosphorus including symbiotic nitrogen fixation and phosphatase production. Jurnal Global Biogeochemical Cycles. 21 (10): 1018-1029. 
Wibisono, A dan P. Basri. 1993. Pemanfaatan Limbah Organik Untuk Pupuk. Buletin Perkebunan, Medan.

Widjanarko, S. 2003. Harta Terpendam di Gunung Kidul Satu Per Satu Diketemukan. Yayasan Acintyacunyata, Yogyakarta. 